\title{
Importância da Moral Kantiana no Ensino de Bioética: Relato de Experiencia
}

\author{
Soares; Sônia \\ Universidade Federal do Rio Grande do Norte — sonia.fil@bol.com.br
}

INTRODUÇÃO: o ensino de bioética é relativamente recente no Brasil. Relata-se aqui a experiência de introduzir o ensino de bioética em Curso de Nutrição, tendo como referencial algumas reflexões do filósofo Immanuel Kant. a necessidade de conteúdos éticos na formação do Nutricionista está colocada nas Diretrizes Curriculares Nacionais, onde é possível identificar as implicações éticas presentes em todas as competências e habilidades gerais relacionadas na Resolução nำ 5/2001 da Câmara de Educação Superior do Conselho Nacional de Educação. Além da formação técnica, o Nutricionista deve ter formação generalista, humanista e crítica. Partindo destes pressupostos, apresenta-se e justifica-se o processo de inserção de elementos da filosofia moral kantiana na discussão de temas atuais como o direito humano à alimentação, soberania alimentar, autonomia e dignidade, objetos de reflexão na disciplina de bioética. OBJETIVOS: o objetivo deste trabalho é relatar e refletir sobre minha experiência de inserir reflexões kantianas no ensino de bioética na formação do Nutricionista, durante os anos de 2010-2012. MÉTODOS: Consideram-se na reflexão: o projeto pedagógico do curso, a ementa da disciplina, as diretrizes curriculares nacionais para cursos de graduação em Nutrição, e a importância de alguns elementos da filosofia kantiana para o ensino da disciplina. RESULTADOS: o Projeto Pedagógico do Curso (PPC) reafirma o compromisso de formar Nutricionistas que tenham "competências e habilidades para realizar seus serviços dentro dos mais altos padrões de qualidade e dos princípios da ética/bioética, tendo em conta que a responsabilidade da atenção à saúde não se encerra com o ato técnico, mas sim, com a resolução do problema de saúde, tanto em nível individual como coletivo" (Res. n ${ }^{\circ} 5 / 2001$, art.4ํ); sendo a saúde um direito humano e social, esta formação deve contemplar as necessidades sociais da saúde, com ênfase no SUS, e valorizar as dimensões éticas e humanísticas, visando desenvolver atitudes e valores orientados para a cidadania e para a solidariedade. a Constituição Brasileira estabelece a cidadania e a dignidade da pessoa humana como fundamentos do Estado Democrático de Direito (art. 1ํ). Todos estes aspectos podem ser abordados no ensino de bioética, à luz da moral kantiana. Assim sendo, utiliza-se a doutrina dos deveres para consigo para introduzir a questão moral nas escolhas alimentares, extrapolando o âmbito jurídico-político do direito à alimentação e dever do Estado; o princípio da autonomia, considerado por Kant como liberdade positiva, é contraposto ao princípio da autonomia da bioética e relacionado à dignidade humana como valor moral, além de ter profundas relações com a noção de soberania alimentar. CONCLUSÕES: o ensino de bioética não pode prescindir de reflexões filosóficas. a filosofia moral kantiana é um importante referencial para debater o direito humano à alimentação e a autonomia das escolhas alimentares como temas atuais da bioética.

Soares; Sônia. Importância da Moral Kantiana no Ensino de Bioética: Relato de Experiencia. In: Anais do Congresso Internacional de Humanidades \& Humanização em Saúde [= Blucher Medical Proceedings, num.2, vol.1]. São Paulo: Editora Blucher, 2014. ISSN 2357-7282

DOI 10.5151/medpro-cihhs-10281 